JASEM ISSN 1119-8362

All rights reserved
Full-text Available Online at www.bioline.org.br/ja
J. Appl. Sci. Environ. Mgt. September, 2006

Vol. 10 (3) $175-181$

\title{
Evaluation of the Abidjan lagoon pollution
}

\author{
BRITON BI, G H; *YAO, B; ADO, G
}

Institut National Polytechnique Houphouët-Boigny, Laboratoire des Procédés Industriels de Synthèse et de l'Environnement (LAPISEN).Département Génie Chimique et Agroalimentaire. B.P. 1093 Yamoussoukro, Cote d'Ivoire.

\begin{abstract}
The Abidjan lagoon pollution evaluation via the physicochemical and biochemical characteristics of effluents pouring in it, in order to take decision concerning the installation of a treatment station was reported. All samples of effluents studied contain high quantity of organic and mineral pollutants except for samples from a hospital (effluent II). However, the analysis of the ratios COD/BOD of the different effluents showed that the corresponding wastewaters have a domestic character and are therefore easily biodegradable. @JASEM
\end{abstract}

Water pollution is a major problem in the great agglomerations in general and African in particular. Because of relatively lenient legislations, industries reject without fear, in the sewers, their untreated waste effluents. Those are finally driven in the urban lakes and lagoons. In addition, the conjugation of the failure of the systems of cleansing and the strong demographic growth of these cities involve strong pressures on these lakes by the polluted runoffs that flow there. The town of Abidjan, one of the most modern metropolises west Africa has known a strong demographic growth in the Sixties and Seventies characterized by a migratory flow and an annual growth rate of about $10 \%$. Today this growth rate is around $4.3 \%$. A recent study taking into account this growth rate and the demographic data of 1990-1996, indicates a current population of about 3.6 millions. This demographic pressure is for a great part at the origin of many environmental problems. The lagoon which crosses the city receives the industrial and domestic wastewaters coming from various districts of the city. In order to evaluate the impact of these rejections, on the quality of this lagoon water and to appreciate the opportunity of installing a treatment station, a study was carried out to determine the physicochemical and biochemical parameters of the principal effluents flowing in it. The Cocody district bay, representative of the state of advanced pollution of the lagoon was selected as a model study.

\section{MATERIAL AND METHODS}

Study area: The lagoon of Abidjan with a surface of $566 \mathrm{~km}$ (Varlet, 1978; Lanusse, 1987) is the vastest of West Africa. This lagoon also receives by the means of Cocody bay, five effluents (I, II, III, IV, V) coming from the Northern part of the Abidjan city, fig 1.

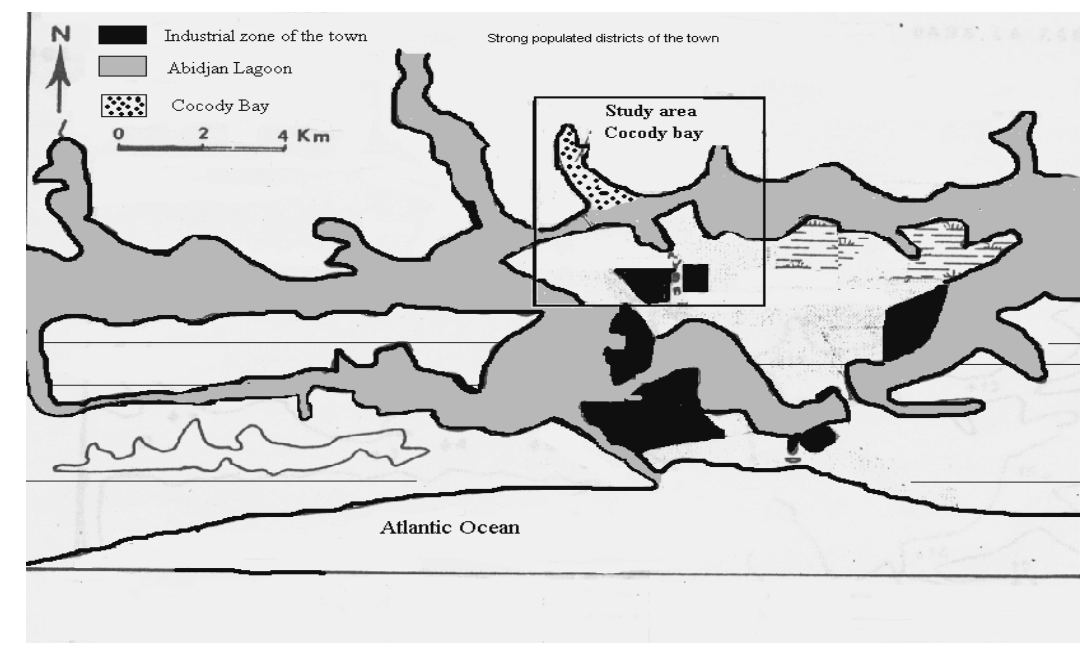

Fig. 1. Study area (Dufour et Slepouka, 1975)

*Corresponding author: beyao@yahoo.fr 
Sampling and analytical methods: The pollution level was appreciated by a series of measurements of total parameters, making it possible to translate with more or less fidelities, the harmful effects likely to be induced in the receiving medium by each effluent. The water samples to be analyzed were taken using polyethylene bottles (500 and $1000 \mathrm{~mL}$ ) during three campaigns corresponding respectively to the rainy season, the beginning and the end of dry season. For each effluent, four samples were taken at different points in order to take account of horizontal heterogeneity. The sampling containers were carefully washed and then rinsed with the water of the effluent prior to be used. They are immersed vertically to approximately $10 \mathrm{~cm}$ of the surface of water and are filled to the brim. The physicochemical parameters such as temperature, dissolved oxygen, $\mathrm{pH}$ and conductivity were performed on the site of taking away. The samples were acidified by sulphuric acid to bring back the $\mathrm{pH}=2$ according to standard NF T 90-513. The containers were then hermetically closed and placed in a refrigerator.

\section{RESULTS AND DISCUSSIONS}

The temperature: According to fig 2, the average of temperature during these campaigns is relatively high and close to $27^{\circ} \mathrm{C}$ particularly the effluent II whose temperature is about $29^{\circ} \mathrm{C}$. This difference is due to the fact that, effluent II comes from a big health center. The relatively high level of the temperature (characteristic of the tropical zone) plays a fundamental role in the kinetics of the biological and physicochemical reactions, as well as the value of the equilibrium constants of these reactions (Vogel, 1970; Varlet, 1978).

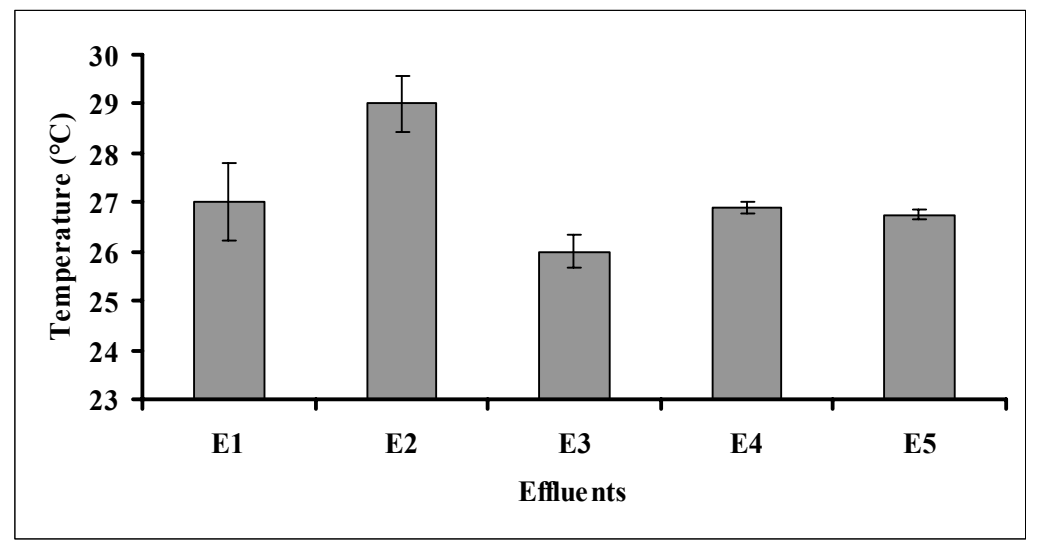

Fig. 2. Average value and standard deviation of the temperature for each effluent

Suspended matter (SM): Fig. 3 represents the average values of the suspended matter (SM) of the effluents. Except for effluent II, the others present high SM, with a maximum $(68.35 \%)$ provided by effluent IV (fig 3 and 4). This effluent, coming from the strongly populated districts brings significant quantities of organic and mineral non-dissolved matter that increases the pollution rate. So, the mud formation to the embouchure of the effluents is observed, and consequently the progressive reduction of the bay surface.

Table 1: ratio COD/BOD of the effluents

\begin{tabular}{cccccc}
\hline & Effluent I & Effluent II & Effluent III & Effluent IV & Effluent V \\
\hline COD $(\mathrm{mg} / \mathrm{L})$ & 239 & 102 & 202 & 1632 & 214 \\
BOD $(\mathrm{mg} / \mathrm{L})$ & 108 & 28 & 108 & 740 & 153 \\
$\mathrm{COD} /$ BOD & 2,2 & 3,7 & 1,85 & 2,2 & 1,4 \\
\hline
\end{tabular}




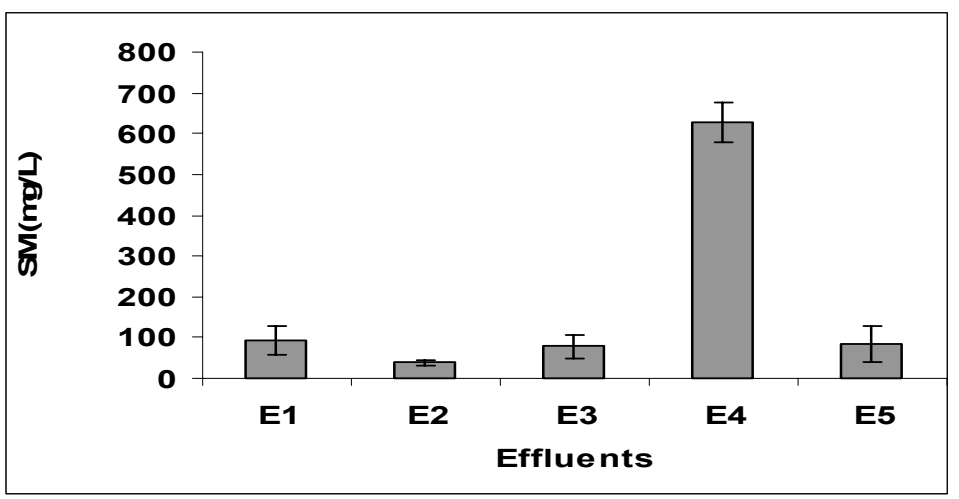

Fig. 3. Average value and standard deviation of SM for each effluent

Dissolved oxygen: According to fig 5 the values of dissolved oxygen are lower than $2 \mathrm{mg} / \mathrm{L}$ and very far from the saturation which is $7.5 \mathrm{mg} / \mathrm{L}$ at $30{ }^{\circ} \mathrm{C}$ (Gaujous, 1995). These low values are due to the presence of strong contents of suspended matter (biodegradable and mineral organic matter in suspension) reducing the quantity of oxygen via oxidation reaction. This analysis is globally confirmed by the plotting of the dissolved oxygen as a function of SM (fig 6). Moreover, it is necessary to note the action of the aerobic micro-organisms that use dissolved oxygen to degrade the organic matter of the effluent. That involves the appearance of an anoxia zones in bay. It results from it, the formation of gas such as $\mathrm{CH}_{4}, \mathrm{H}_{2} \mathrm{~S}$ and of iron sulphide $(\mathrm{FeS})$ (Gaujous, 1995), due to the fermentation of the organic compounds by the anaerobic bacteria in the deoxygenized medium, and consequently the release of bad smells to the periphery of the bay.

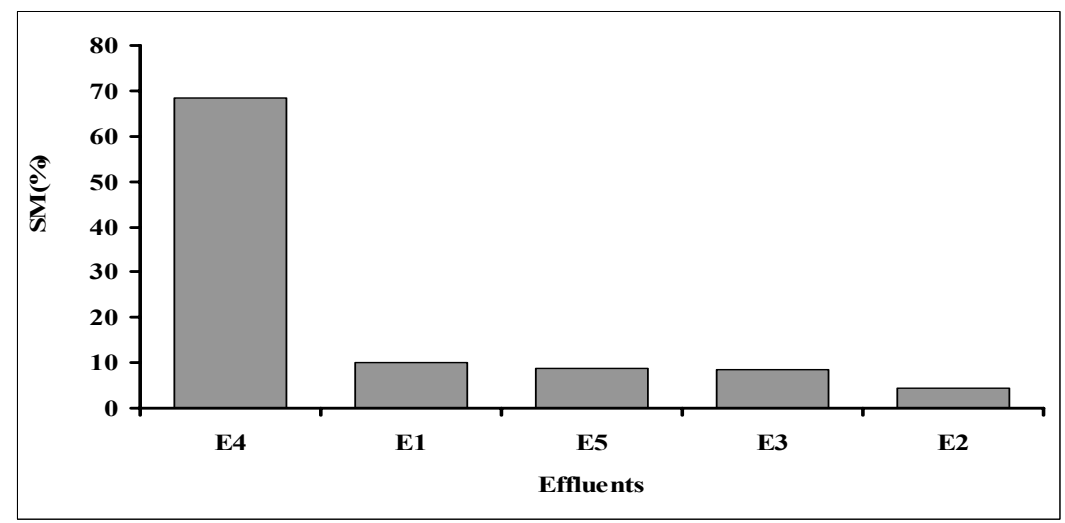

Fig. 4. The SM contribution of each effluent on the whole of the contributions

Conductivity: Generally, waters mineralization is supposed very weak, when its conductivity is lower than $1000 \mu \mathrm{S} / \mathrm{cm}$ and very high, when it is beyond $1000 \mu \mathrm{S} / \mathrm{cm}$ (Rodier, 1984). On this basis the effluents I, II, III and V have a relative weak average conductivity compared to the effluent IV one that is higher than $1000 \mu \mathrm{S} / \mathrm{cm}$ as shown by fig 7 . The difference in conductivity between effluent IV and the others is related to their origins. Indeed, effluent IV comes from two strongly populated district of Abidjan with household and toilet waters very charged in mineral salt. These effluents partly increase the rate of mineralization of bay and involve a rise in conductivity. This assertion is well justified by conductivity to the embouchure of the effluents which is of $63000 \mu \mathrm{S} / \mathrm{cm}$. However, this strong conductivity of the receiving medium is not only the fact of the effluents, but also of water of the sea that communicates with the lagoon by a channel.

$p H$ : The basicity of the effluents is observed (fig 8), and is very marked for effluents I and IV with values of $\mathrm{pH}$ slightly higher than 10 . These remarkable values would be due to the use of detergents for scrubbing. These values could have a negative impact on the life of the watery species and would on the other hand support the proliferation of the bacteria such as Nitrosomonas and Nitrobacters responsible of the nitritation and the nitratation, that occur at $\mathrm{pH}$ ranging between 6.6 and 10 (Atlas et Bartha, 1981).

Briton Bi, G H; Yao, B; Ado, G 


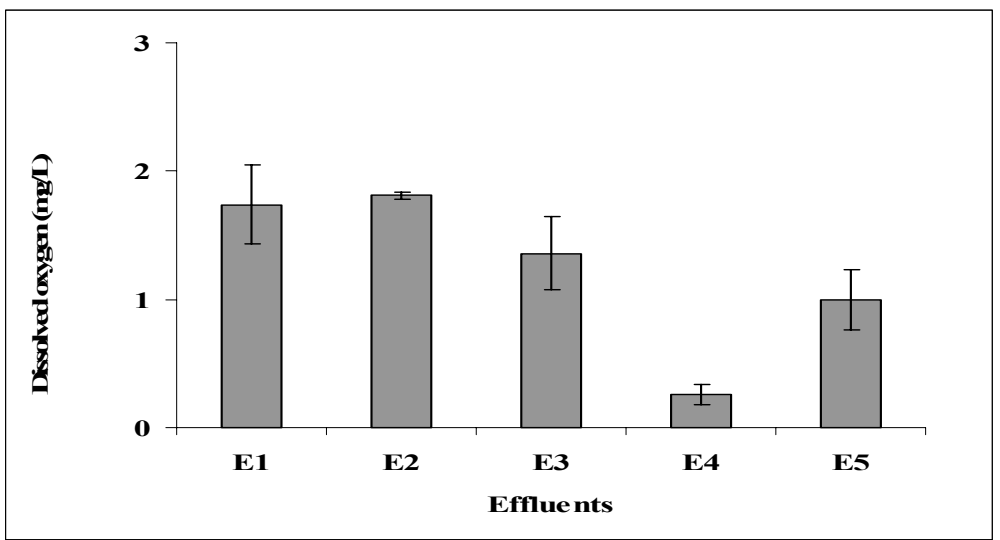

Fig. 5. Average value and standard deviation of the dissolved oxygen for each effluent

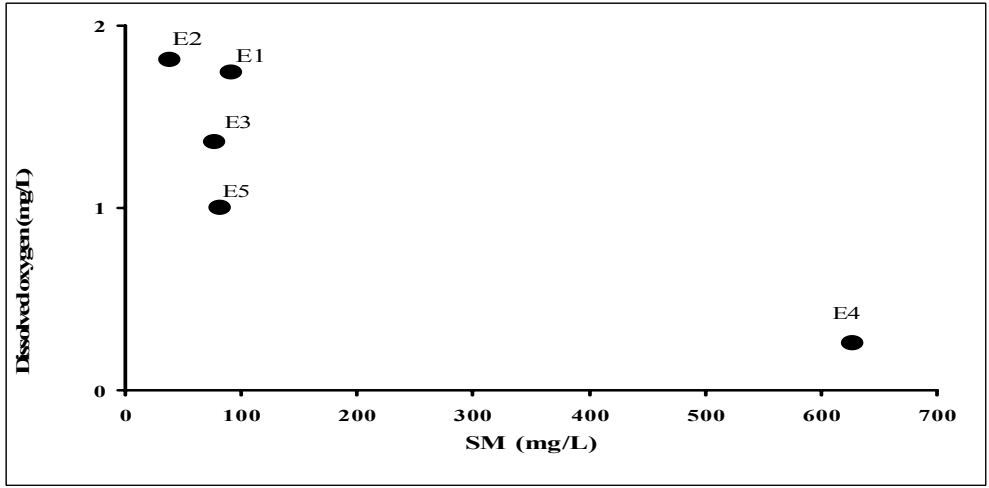

Fig. 6. Dissolved oxygen as a function of SM

Chemical Oxygen Demand (COD): When taking account of the standards of wastewaters whose acceptable maximum threshold in COD ranges from 120 to $150 \mathrm{mg} / \mathrm{L}$, the ones of the effluents (fig 9) are very high except for effluent II, particularly the effluent IV whose average of COD is $1632 \mathrm{mg} / \mathrm{L}$. These values are in good agreement with the low contents dissolved oxygen of the medium. The evolution of conductivity and SM as a function of COD (fig 10) show the effectiveness dependence of the COD with these parameters. Indeed, the high values of the one of the two parameters involve a rise of the COD.

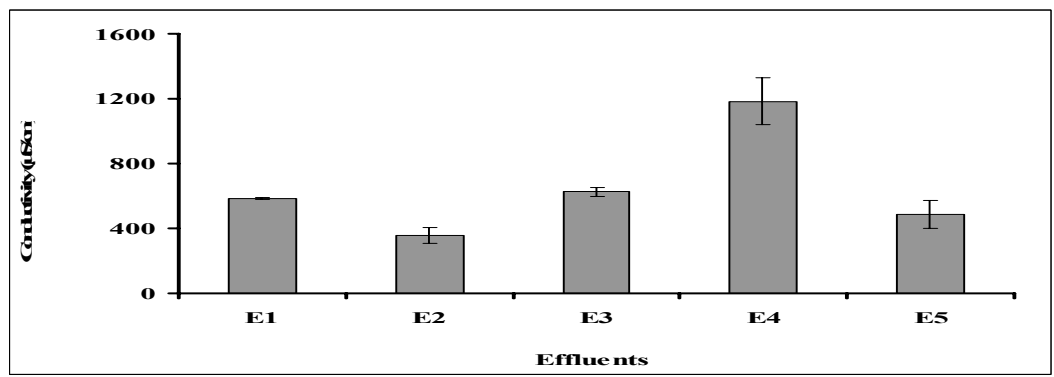

Fig. 7. Average value and standard deviation of conductivity for each effluent

Biochemical oxygenates demand (BOD): The BOD varies from an effluent to another. The domestic waters constituting effluent II present a very weak BOD (fig 11). For this effluent the average value is Briton Bi, G H; Yao, B; Ado, G
$28 \mathrm{mg} / \mathrm{L}$. Consequently, the rejection of this effluent in bay could not constitute a danger. On the other hand, effluent IV presents a BOD very significant 
(740 mg/L). This value confirms the effective presence of a significant organic load.

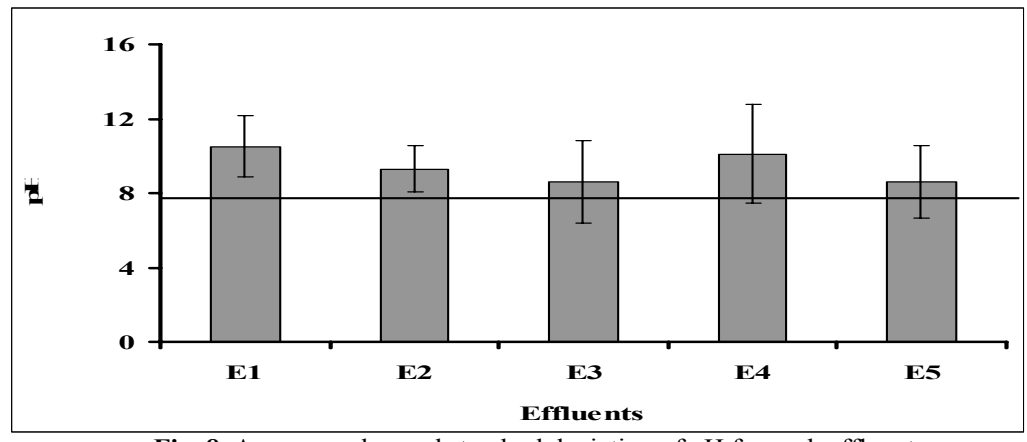

Fig. 8. Average value and standard deviation of $\mathrm{pH}$ for each effluent

Nitrogen total (NTK): Total nitrogen contents of the effluents are illustrated by fig 12 . Effluents IV and V, and to a lesser extent effluent III, provide the greatest rates of total nitrogen. The case of effluent IV is due to wastewaters coming from the strongly populated district of Abidjan. This considerable nitrogen contribution enriches bay in nutritive elements and contributes to the eutrophication of the system (Thornton and Nduku, 1982; Zaret et al, 1981; Henryet et al, 1985).

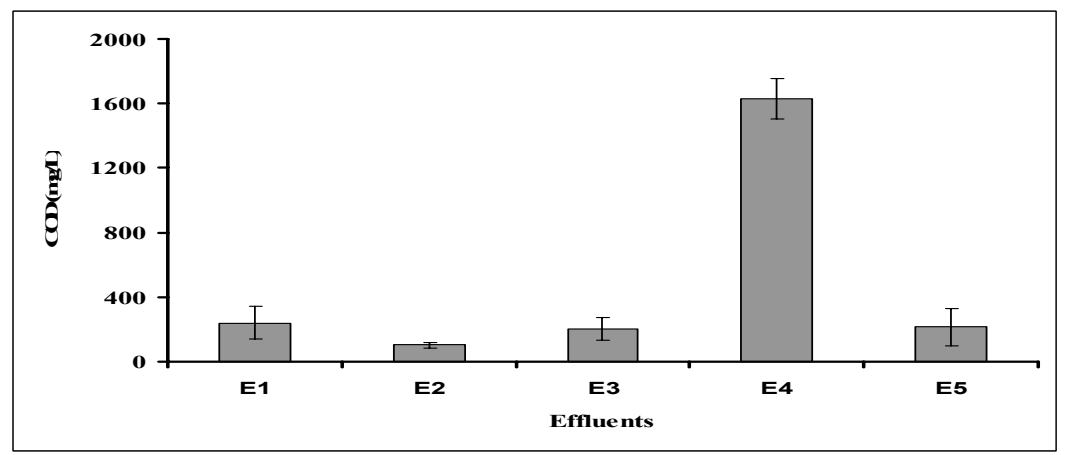

Fig. 9. Average value and standard deviation of the COD for each effluent

Total phosphorus: According to fig 13, the effluents I, III and V present total phosphorus contents rather close. The case of effluent IV is most notable because of a phosphorus average estimated to $15.8 \mathrm{mg} / \mathrm{L}$. This phosphorus concentration would be the consequence of the strong density of population of the various districts and the use of manures for urban agricultural activities. It appears that the effluents are partly responsible of the development of the watery plants on bay by their contributions in nutritive elements

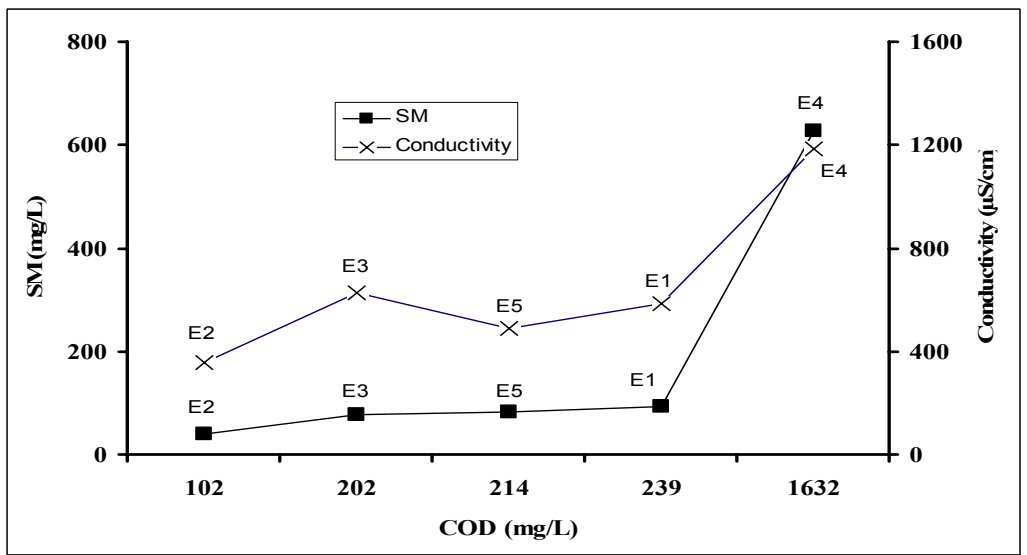

Briton Bi, G H; Yao, B; Ado, G 
Fig. 10. Conductivity and SM as a function of COD

Characterization of the effluents: The characterization of the effluents passes by the determination of the relationship between the organic pollution parameters. The ratio COD/BOD indicates the relative share of the matters quickly biodegradable in the whole of the oxydable matters (Cardot, 1999). By considering the average of the
COD and BOD of the effluents, it was established $\mathrm{COD} / \mathrm{BOD}$ ratio consigned in table 1 . The bibliography indicates that $\mathrm{COD} / \mathrm{BOD}$ ratio for domestic waste water is equal to 2 (Bechac, 1983). So, except for effluents II and V, the other effluents present $\mathrm{COD} / \mathrm{BOD}$ ratios equal to 2 and can be regarded as domestic effluents.

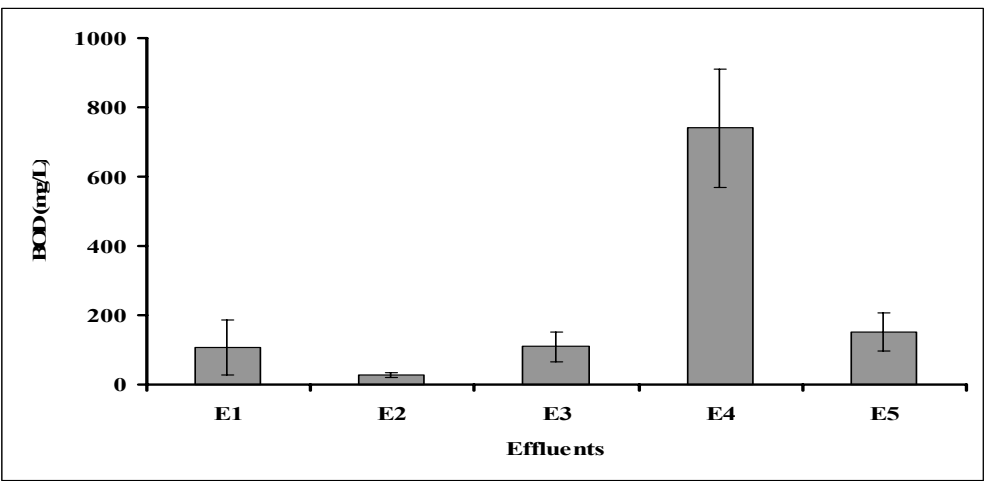

Fig. 11. Average value and standard deviation of BOD for each effluent

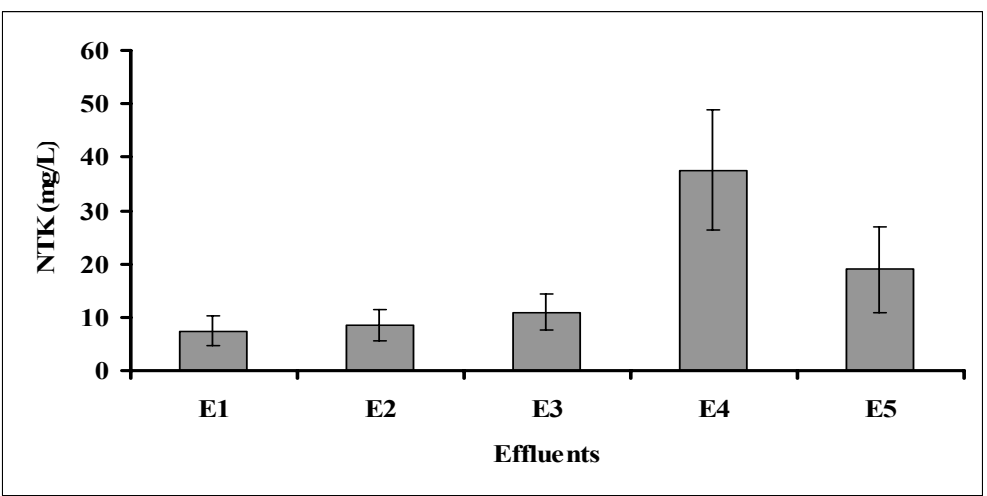

Fig. 12. Average value and standard deviation of total nitrogen for each effluent

Conclusion: The results observed on the five effluents flowing in bay showed that those are charged in biodegradable organic pollutants and in nutritive pollutants except for effluent II. Effluent IV coming from the strongly populated districts is the most polluted. It appears that the resolution of the pollution problems of the bay passes by a treatment of each effluent, particularly the IV one

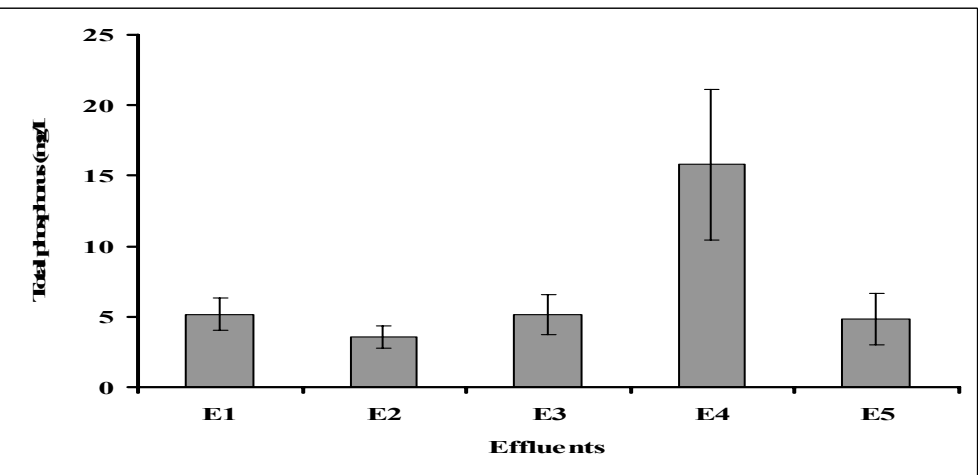

Briton Bi, G H; Yao, B; Ado, G 
Fig 13. Average value and standard deviation of total phosphorus for each effluent

\section{REFERENCES}

Atlas, R.M; Bartha, R (1981). Microbial ecology : fundamentals and applications. Ed. Addison Wesley

Bechac, J.P; Boutin, P; Mercier, B; Nuer, P (1983). Traitement des eaux usées,.

Cardot, C (1999). Les traitements de l'eau : Procédés physico-chimiques et biologiques. Cours et problèmes résolus. Génie de l'environnement.

Dufour, P; Slepouka, M (1975) l'oxygène dissous en Lagune Ebrié (Cote d'Ivoire) : influences de l'hydroclimat et des pollutions. In : Doc. Scient. CNRO, $6: 77-78$.

Girard, G; Sircoulon, J; Touchebeuf (1971). Milieu naturel de la Côte d'Ivoire. Aperçu sur les régimes hydrologiques. Mémoire ORSTOM, Paris, 50 : 109-155.

Gaujous, D (1995). La pollution des milieux aquatiques, $2^{\mathrm{e}}$ édition.

Henry, R; Hino, K; Tudisi, J.G; Ribiero, J.S.B (1985). Response of phytoplankton in lake jacaretinga to enrichment with nitrogen and phosphorus in concentration similar to those of the river solimoes (Amazon, Brazil), Arch. Hydrobiol., 103: 453-477.
Lanusse, A (1987). Contamination microbienne d'une lagune tropicale (lagune Ebrié, Côte d'Ivoire): influences de l'hydroclimat. Thèse, université de Provence (Aix-Marseille I)

Rodier, J (1984). L'analyse chimique et physicochimique de l'eau: eaux naturelles; eaux résiduaires. $4^{\mathrm{e}}$ éd, Paris: DUNOD, p 700.

Thornton, J A; Nduku, WK (1982). Water chemistry and nutrients budgets. In: Thornton J.A, Lake MCLL Waine, the eutrophication and recovery of tropical African man-made Lake. Monographiae biological, Junk Publishes, the Netherlands, 49: 4349.

Varlet (1978). Régime de la lagune Ebrié (Côte d'Ivoire) trait physique essentiel. Travaux doc. CNRO, p 164.

Vogel, G; Angenmann, H (1970). Atlas de biologie. Stock, Paris

Zaret, T M; Devol, A H; Santos, A D (1981). Nutrient addition experiment in Lago Jacaretinga, Central Amazon basin, Brazil. Verh. Internat. Verein. Limnol., 21: 721-724. 